\title{
Virulence Properties of Oral Bacteria: Impact of Molecular Biology
}

\author{
Howard K. Kuramitsu* \\ Department of Oral Biology, State University of New York \\ Buffalo, NY 14214, USA
}

\begin{abstract}
Dental caries and periodontitis, although generally not life threatening, are nevertheless of significant importance. An understanding of the molecular nature of these diseases could aid the development of novel methods of prevention and control, and increase our knowledge of their etiology. The identification of virulence factors in oral bacteria could lead to the development of vaccines directed against these organisms, the design of inhibitors of biofilm formation, and the development of replacement therapy strategies.
\end{abstract}

Two of the most common human diseases are the oral infections dental caries and periodontitis. Although neither disease is generally considered life threatening, both can be painful as well as costly. In addition, more recent evidence has suggested a potential role of periodontal infections in more serious systemic diseases including cardiovascular disease, respiratory infections, diabetes, and low-birth weight complications (Li et.al., 2000). Although the application of good oral hygiene practices together with fluoridation is generally considered to be primarily responsible for the continuing decline in dental caries in industrialized countries, a significant proportion of the population still suffers from tooth decay. Therefore, a more thorough understanding of the molecular basis for these diseases should prove useful in diagnosing those at greatest risk for disease progression as well as perhaps providing novel preventative approaches. As with other infectious diseases, the application of molecular biological approaches has been crucial in increasing our understanding of the etiology of both caries and periodontitis.

Almost forty years ago it was recognized that the mutans streptococci, primarily Streptococcus mutans, played an important role in cariogenesis (Hamilton, 2000). Biochemical approaches identified three important unique properties of these organisms which appear to be important in disease initiation: aciduricity, acidogenesis, and sucrosedependent colonization. Beginning with the pioneering work of R. Curtiss III's laboratory (Kuramitsu, 2000), molecular genetic approaches have helped to characterize the virulence factors of the mutans streptococci. The

*For correspondence. Email kuramits@acsu.buffalo.edu; Tel. 716-8292068; Fax. 716-8293942. identification of natural transformation in some, but not all, strains of $S$. mutans was soon exploited to construct monospecific mutants. These mutants implanted into caries-susceptible rodents proved invaluable in identifying virulence factors in these organisms. The rapid conversion of dietary sugars such as sucrose to lactic acid could be explained in terms of the multiple pathways which $S$. mutans strains express. Many of the genes involved have been isolated, characterized, and their regulatory mechanisms examined (Kuramitsu, 2000). Likewise, several different genes which affect the aciduricity of these organisms have also been identified and it is likely that this property is influenced by multiple factors (Hamilton, 2000).

Much attention has been focused on the mechanism by which $S$. mutans colonizes tooth surfaces. Both biochemical and genetic approaches suggest that this occurs via a two-step process: a sugar independent attachment to the tooth pellicle modulated by $S$. mutans adhesins, ionic or hydrophobic interactions, as well as impaction of the crevices on the tooth surface followed by a sucrose-dependent enhancement of tooth colonization. A number of laboratories have isolated and characterized the gene for an adhesin (termed SpaP, antigen I/II, Pac) which appears to modulate the initial attachment of $S$. mutans to saliva-coated tooth surfaces (Kuramitsu, 2000). More recently, a spaP mutant has been demonstrated to be attenuated in smooth surface caries formation in rats (Crowley et.al., 1999). Several laboratories have also isolated the multiple glucosyltransferases (gtf) genes of mutans streptococci involved in sucrose-dependent colonization. Mutants defective in each of the $S$. mutans gtf genes were also demonstrated to be attenuated in smooth surface caries formation in rats (Kuramitsu, 2000). In addition, the identification and characterization of multiple glucan-binding proteins from these organisms has suggested a role for these proteins in sucrose-dependent tooth colonization (Kuramitsu, 2000).

Inflammation of the periodontal tissue leading ultimately to alveolar bone loss appears to result from the combined action of a several gram-negative anaerobic bacteria (Grenier and Mayrand, 2000). Although a number of bacteria which could contribute to periodontitis may yet remain to be identified, the utilization of DNA probes has implicated three organisms with chronic periodontal lesions: Porphyromonas gingivalis, Bacteroides forsythus, and Treponema denticola. In addition, Actinobacillus actinomycetemcomitans has been associated with a specialized form of periodontitis referred to as localized aggressive periodontitis. These organisms express a variety of potential virulence factors and are capable of inducing inflammatory reactions which are thought to be important in tissue destruction. In this regard, considerable interest has focused on the leukotoxin produced by $A$. actinomycetemcomitans and the gene for this virulence 
factor has been isolated and characterized. In addition, the tissue invasive properties of these organisms as well as $P$. gingivalis are under investigation using molecular genetic approaches (Lamont and Jenkinson, 2000). $P$. gingivalis has also been extensively studied and both biochemical and genetic approaches have identified fimbrae and the gingipain proteinases as important virulence factors. The former has been implicated in $P$. gingivalis colonization of tooth surfaces, interaction with and invasion of host cells, as well as induction of alveolar bone loss. Furthermore, the construction of afimbriated mutants following inactivation of the fimA gene has also resulted in virulence attenuation in a rat model system. The proteinases of $P$. gingivalis have also been implicated in tissue destruction, increases in vascular permeability, avoidance of host immune mechanisms, as well as the dissolution of blood clots.

Although much less is known regarding the potential virulence factors of $B$. forsythus and $T$. denticola, the recent development of gene transfer systems for both organisms (Sharma, 2000; Li et.al., 1996) should help fill this void. Genes for chemotaxis, interaction with host tissue, as well as a major serine proteinase have been isolated from the oral spirochete (Fenno and McBride, 1998). In addition, the recent sequencing of the genomes of $A$. actinomycetemcomitans, $P$. gingivalis and $T$. denticola in conjunction with gene expression technologies should enhance the identification of pathogenic factors in these organisms.

One important area of research to which oral microbiology can make major contributions is in our understanding of the molecular basis for biofilm formation (Marsh, 2000). The relative advantage of investigating biofilm formation in situ in the oral cavities of humans or animals coupled with the availability of genetic systems to manipulate bacteria normally isolated from plaque biofilms, makes such studies readily feasible. Thus, the utilization of mutants, reporter gene fusions (including fluorescent constructs), differential display or DNA microchips in these systems should lead to significant increases in our understanding of the regulation of biofilm formation.

The results of molecular biological analyses may also suggest novel approaches for controlling oral infections. The identification of virulence factors in the etiologic bacteria could lead to the development of vaccines directed against these organisms, the design of inhibitors of biofilm (dental plaque) formation, as well as replacement therapy strategies (Kuramitsu, 1993). Thus, the new millennium offers much promise for more effective preventive approaches against common dental infections based upon molecular analysis.

\section{References}

Crowley, P.J., L.J. Brady, S.M. Michalek, and A.S. Bleiweis. 1999. Virulence of a spaP mutant of Streptococcus mutans in a gnotobiotic rat model. Infect. Immun. 67: 1201-1206.

Fenno, J.C. and B.C. McBride. 1998. Virulence factors of oral treponemes. Anaerobe 4: 1-17.

Grenier, D., and D. Mayrand. 2000. Periodontitis as an ecological imbalance. In Oral bacterial ecology: the molecular basis (H.K. Kuramitsu and R.P. Ellen, eds.). Horizon Scientific Press, Norfolk, U.K. pp. 275-310.

Hamilton, I.R. 2000. Ecological basis for dental caries. In Oral Bacterial Ecology: the molecular basis (H.K. Kuramitsu and R.P. Ellen, eds). Horizon Scientific Press, Norfolk, U.K. pp. 219-274.

Kuramitsu, H.K. 1993. Virulence factors of mutans streptococci: role of molecular genetics. Crit. Rev. Oral Biol. Med. 4: 159-176.

Kuramitsu, H.K. 2000. Streptococcus mutans: molecular genetic analysis. In Gram-positive pathogens (V.A. Fischetti et.al., eds). American Soc. Microbiol., Washington, D.C. pp. 280-286.

Lamont, R.J., and H.F. Jenkinson. 2000. Adhesion as an ecological determinant in the oral cavity. In Oral Bacterial Ecology: the molecular basis (H.K. Kuramitsu and R.P. Ellen, eds). Horizon Scientific Press, Norfolk, U.K. pp. 131-168.

Li, H., J. Ruby, N. Charon, and H. Kuramitsu. 1996. Gene inactivation in the oral spriochete Treponema denticola: construction of a flgE mutant. J. Bacteriol. 178: 36643667.

Li, X., K.M. Kolltveit, L. Tronstad, and I. Olsen. 2000. Systemic diseases caused by oral infection. Clin. Microbiol. Rev. 13: 547-558.

Marsh, P.D. 2000. Oral ecology and its impact on oral microbial diversity. In Oral Bacterial Ecology: the molecular basis (H.K. Kuramitsu and R.P. Ellen, eds). Horizon Scientific Press, Norfolk, U.K. pp. 11-65.

Sharma, A. 2000. Personal communication. 


\section{Further Reading}

Caister Academic Press is a leading academic publisher of advanced texts in microbiology, molecular biology and medical research. Full details of all our publications at caister.com

- MALDI-TOF Mass Spectrometry in Microbiology Edited by: M Kostrzewa, S Schubert (2016) www.caister.com/malditof

- Aspergillus and Penicillium in the Post-genomic Era Edited by: RP Vries, IB Gelber, MR Andersen (2016) www.caister.com/aspergillus2

- The Bacteriocins: Current Knowledge and Future Prospects Edited by: RL Dorit, SM Roy, MA Riley (2016)

www.caister.com/bacteriocins

- Omics in Plant Disease Resistance Edited by: V Bhadauria (2016) www.caister.com/opd

- Acidophiles: Life in Extremely Acidic Environments Edited by: R Quatrini, DB Johnson (2016) www.caister.com/acidophiles

- Climate Change and Microbial Ecology: Current Research and Future Trend

Edited by: J Marxsen (2016)

www.caister.com/climate

- Biofilms in Bioremediation: Current Research and Emerging Technologies

Edited by: G Lear (2016)

www.caister.com/biorem

- Microalgae: Current Research and Applications Edited by: MN Tsaloglou (2016) www.caister.com/microalgae

- Gas Plasma Sterilization in Microbiology: Theory, Applications, Pitfalls and New Perspectives Edited by: H Shintani, A Sakudo (2016) www.caister.com/gasplasma

- Virus Evolution: Current Research and Future Directions Edited by: SC Weaver, M Denison, M Roossinck, et al. (2016) www.caister.com/virusevol

- Arboviruses: Molecular Biology, Evolution and Control Edited by: N Vasilakis, DJ Gubler (2016) www.caister.com/arbo

- Shigella: Molecular and Cellular Biology Edited by: WD Picking, WL Picking (2016) www.caister.com/shigella

-Aquatic Biofilms: Ecology, Water Quality and Wastewater Treatment

Edited by: AM Romaní, H Guasch, MD Balaguer (2016)

www.caister.com/aquaticbiofilms

- Alphaviruses: Current Biology

Edited by: S Mahalingam, L Herrero, B Herring (2016)

www.caister.com/alpha

- Thermophilic Microorganisms

Edited by: F Li (2015)

www.caister.com/thermophile
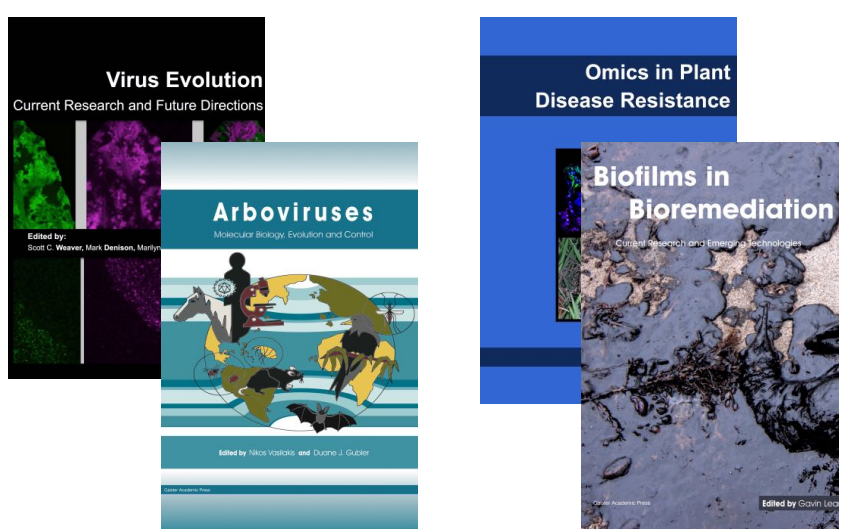
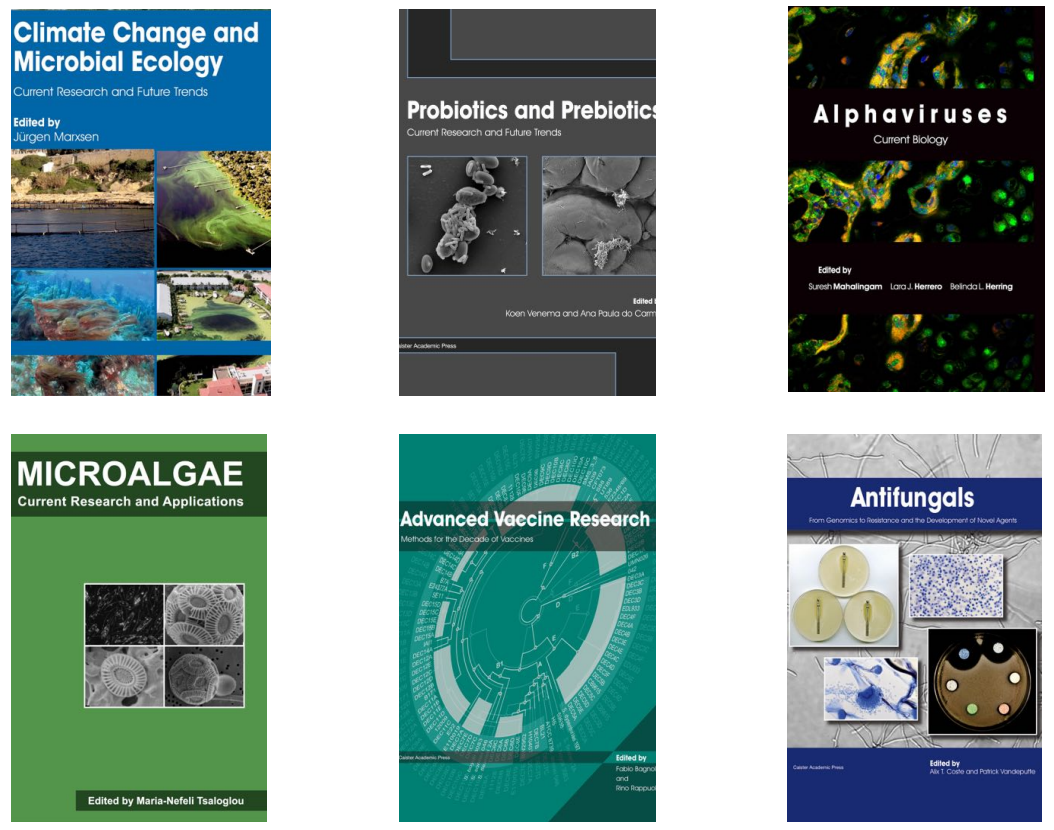

- Flow Cytometry in Microbiology: Technology and Applications Edited by: MG Wilkinson (2015) www.caister.com/flow

- Probiotics and Prebiotics: Current Research and Future Trends Edited by: K Venema, AP Carmo (2015) www.caister.com/probiotics

- Epigenetics: Current Research and Emerging Trends Edited by: BP Chadwick (2015) www.caister.com/epigenetics2015

- Corynebacterium glutamicum: From Systems Biology to Biotechnological Applications

Edited by: A Burkovski (2015)

www.caister.com/cory2

- Advanced Vaccine Research Methods for the Decade of Vaccines

Edited by: F Bagnoli, R Rappuoli (2015)

www.caister.com/vaccines

- Antifungals: From Genomics to Resistance and the Development of Novel Agents

Edited by: AT Coste, P Vandeputte (2015)

www.caister.com/antifungals

- Bacteria-Plant Interactions: Advanced Research and Future Trends Edited by: J Murillo, BA Vinatzer, RW Jackson, et al. (2015) www.caister.com/bacteria-plant

\section{- Aeromonas}

Edited by: J Graf (2015)

www.caister.com/aeromonas

- Antibiotics: Current Innovations and Future Trends

Edited by: S Sánchez, AL Demain (2015)

www.caister.com/antibiotics

- Leishmania: Current Biology and Contro Edited by: S Adak, R Datta (2015) www.caister.com/leish2

- Acanthamoeba: Biology and Pathogenesis (2nd edition) Author: NA Khan (2015)

www.caister.com/acanthamoeba2

- Microarrays: Current Technology, Innovations and Applications Edited by: Z He (2014)

www.caister.com/microarrays2

- Metagenomics of the Microbial Nitrogen Cycle: Theory, Methods and Applications

Edited by: D Marco (2014)

www.caister.com/n2 